\title{
2D stability and flow analysis of a slope in Recife - PE with Barreiras Formation soil in unsaturated conditions
}

\author{
Tahyara Fontoura ${ }^{1, *}$, Roberto Coutinho ${ }^{2}$, and Bruno Morais ${ }^{2}$ \\ ${ }^{1}$ Federal Institute of Rio Grande do Norte, DIAC, 59460-000, São Paulo do Potengi, RN, Brasil \\ ${ }^{2}$ Federal University of Pernambuco, GEGEP, 50670-901, Recife, Brasil
}

\begin{abstract}
Due to the increase in the number of mass movements on hillslopes during the rainy season in the city of Recife, the importance of analyzing and understanding the unsaturated behavior of the soil is verified. Therefore, this paper covers the stability analysis of an unsaturated soil belonging to the Barreiras Formation located at an important hillslope of Recife. This area has been affected by landslides in 2000, and about 100 families were left homeless after losing their homes. The slope is approximately $56 \mathrm{~m}$ high and $414 \mathrm{~m}$ long (lined up with Chagas Ferreira Avenue). The results of physical characterization and parameters from shear resistance of soil obtained in laboratory tests are presented. The modeling work was divided in two parts: (1) transient unsaturated seepage analysis; (2) stability analyses. To achieve this, computational solutions were implemented applying the SLOPE / W and SEEP / W programs, which analyzes the stability and flow of the slope. For analyzes, a rainfall of July / 2019 and pontual leaks was considered in the values of of 0.5, 1.0 and $1.5 \mathrm{~m}^{3} /$ day. It was possible to observe that, as the intensity of the leaks increased, the pore water pressure values increased considerably at the deepest levels. The water table was also compatible with the increase in the intensity of water infiltration. In the slope stability analyzes conducted was observed that the increase in moisture content and the decrease in suction during intense precipitation periods combined with leak infiltration reflect in the decrease in the safety factor to values around 1.
\end{abstract}

\section{Introduction}

The Barreiras Formation is one of the most extensive units observed along the Brazilian coast, extending from the State of Rio de Janeiro to the State of Amapá (Suguio and Nogueira 1999 [1]), covering Mesozoic sedimentary deposits from several coastal basins.

In the Metropolitan Region of Recife, the deposits of the Barreiras Formation are unevenly distributed over the crystalline basement and the Cretaceous basins (SubBasin Cabo and Sub-Basin Olinda) reaching up to $150 \mathrm{~m}$ in thickness in the northern area of Recife. The Barreiras Formation, associated with fluvial processes, shows at least three distinct facies: proximal alluvial fan, distal fan / alluvial plain and fluvial channel (Alheiros et al. 1988 [2]). Lithologically, quartz sands, clays and silts are used as sediments from the Barreiras Formation (Silva 2007 [3]). In this context, the predominantly clayey or sandy soils make the slopes susceptible to instability processes, hence the importance of studying the geotechnical characteristics of these materials.

According to Peranick et al. (2019) [4], precipitation in the form of rainfall is the most common landslide cause. Rainfall-induced landslides occur in various geologic, climate, and topographic conditions. Factors primarily controlling rainfall-induced slope failures are both the rainfall characteristics and soil properties. Rain falling on the slope generates a transient infiltration process within the unsaturated zone existing between terrain surface and phreatic line, increasing the soil water content and reducing the matric suction. The later directly affects hydromechanical features of the soil. A decrease of the matric suction causes a reduction of the effective stress and available shear strength. At the same time, increased water content increases the hydraulic permeability of the soil. Quantities such as shear strength, hydraulic permeability and water storage capacity of unsaturated soil depend on the matric suction value, which varies with the water content of soil.

The water retention, unsaturated shear strength, and hydraulic conductivity function are very important unsaturated soil property functions (USPFs). These have to be determined when analyzing the stability of unsaturated slope exposed to transient rainfall infiltration process (e.g., Peranick et al. 2019 [4]).

There are many studies on stability in soils typical of the Barreiras Formation, but few analyze the unsaturated condition of the soil and the effect of transitory rainfall infiltration on the slope stability.

Therefore, this article presents the field and laboratory activities with typical soil of Barreiras Formation and the flow and stability analyzes conducted to investigate the importance of the unsaturated zone for the process of rainfall infiltration and activation of slopes.

* Corresponding author: tahyara.barbalho@ifrn.edu.br 


\section{Description of the Study Area}

The studied hillside is called "Alto de Santa Teresa". The study area location is on a slope in Recife on the Chagas Ferreira Avenue - Passarinho neighbourhood; its geographic coordinates are: $287887.00 \mathrm{E} / 9116055.00 \mathrm{~S}$. Fig. 1 presents the exact slope location.

According to the contour lines found, the slope has a maximum and a minimum altitude of $78 \mathrm{~m}$ and $22 \mathrm{~m}$, respectively. The slope is approximately $56 \mathrm{~m}$ high and $414 \mathrm{~m}$ long (continuing on Chagas Ferreira Avenue).

The spontaneous occupations on the RMR's hills generally occur by invasions and allowable land occupations. This process is the cause of several instability problems on the Recife's slopes.

In August 2000, there was a landslide in the analyzed area, in which about 100 families were left homeless. In April 2018, landslides occurred at the toe of the analyzed slope due to heavy rainfall (around $100 \mathrm{~mm}$ in a few hours.

On July 24, 2019, above-normal precipitation, around $145 \mathrm{~mm}$ in a few hours, occurred and caused several occasional landslides on the slope. Also, it had been raining considerably that month, nearly $500 \mathrm{~mm}$. The landslides that occurred were of a small magnitude and, for the most part, caused by cuts made by the residents, which ended up in the loss of strength due to the increase in soil moisture content. Some houses built at the slope top also presented cracks in their walls and floors, as shown in Fig. 2.

By the time of this paper, there are no stabilization measures, and the process continues to threaten the lives and possessions of many people. These occupations occurs in a disorderly way considering that the lots are obtained through cuts to create a flat terrain. The cut material is released at the edge of the slope without the compaction required for a landfill.

On the studied slope, the occupation model is "Occupation in all planes" that levels the hill's tops and creates a big plateau where the road network and other urban elements are developed - such as lots, buildings, and infrastructure networks, as the occupation model in flat areas. Part of the occupations has buildings with low constructive standards, which indicates extreme poverty conditions. There is no water supply or sanitation network for the buildings that are in the middle of the slope, which leads to the sewage-disposal on the slope itself. This material infiltrates the soil and can influence its behavior.

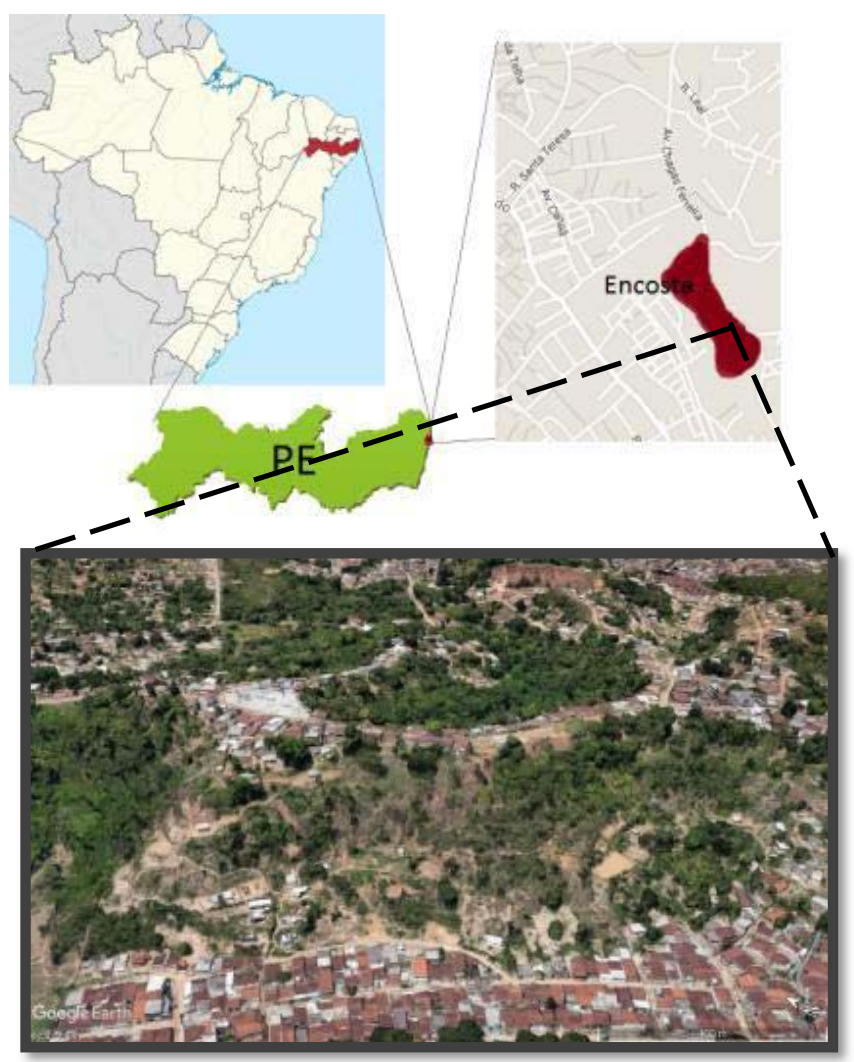

Fig. 1. Studied slope location.

\section{Geological Characterization}

The rocks designated as "Barreiras" were inserted in the category and formation by Mabesoone et al. (1991) [5]. Alheiros et al. (1988) [6] and Alheiros \& Lima Filho (1991) [7] performed geological mappings in the region between Rio Grande do Norte and Pernambuco and observed the Barreiras Formation in the form of conglomeratic sandstones with quartz pebbles, intercalations of clay blocks and tabular crossstratifications .
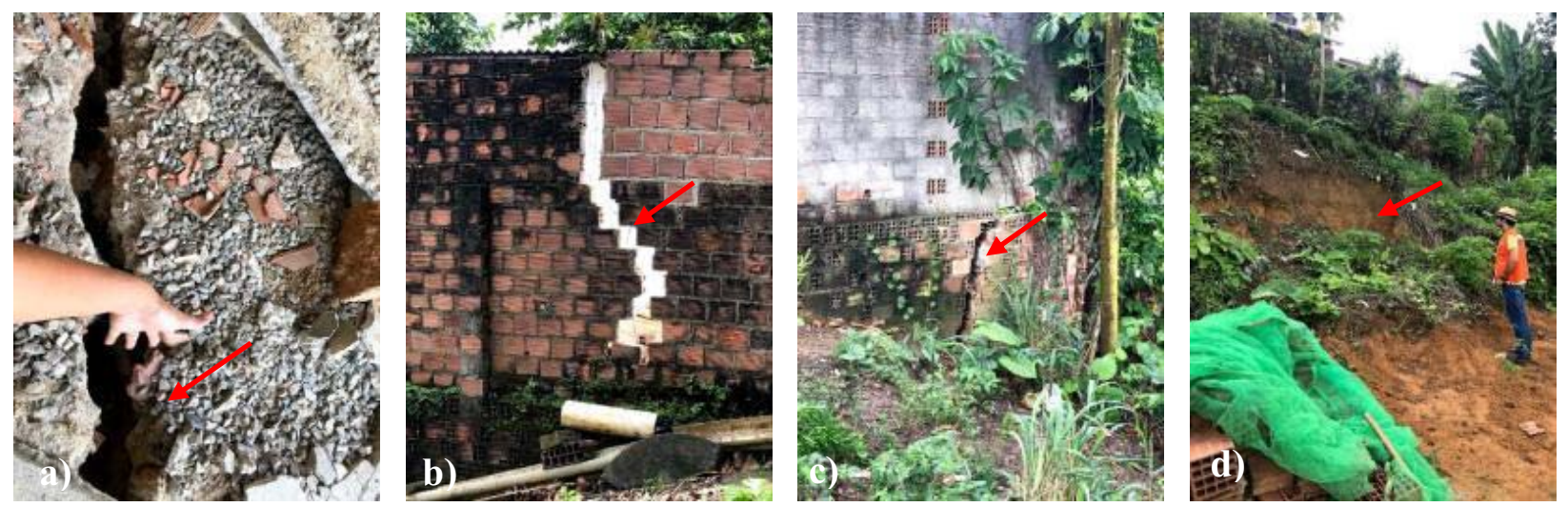

Fig. 2. Location of the (a, b, c) Cracks in the houses and (d)landslide located at the slope top after the rain in July, 2019. 
It was also observed towards the top, sequences of medium to thick cream-colored sandstones with planeparallel stratifications and small intercalations of clay and silt. These same authors concluded that the sedimentary rocks of the Barreiras Formation would have been deposited in an interwoven fluvial environment associated with alluvial fans and coastal deposits.

The geological formation of the slope soil is the Barreiras Formation. Via the geological mapping, it was possible to identify two distinct sedimentary facies for the Barreiras Formation rocks: alluvial fans and fluvial channels/floodplains.

The first facies appears as conglomeratic sediments constituted by centimetric gravel of quartz wrapped in a coarse sandy matrix that generally occurs interspersed with sandy layers; in these layers, sedimentary structures are not present. Besides the gravel, centimetric blocks of ferruginous concretions and clay blocks can also occur. These characteristics indicate that its formation occurred due to processes of high-energy debris flow in an environment of alluvial fans.

\section{Climate}

The climate of the Metropolitan Region of Recife is classified tropical rainy (type $A_{s}{ }^{\prime}$ to $A_{m s}$ ' in the Köppen classification), with total annual precipitation above $750 \mathrm{~mm}$ and average air temperature always above $18^{\circ} \mathrm{C}$. The relative humidity of the air is high, varying between $79.2 \%$ and $90.7 \%$ in the rainiest months, between April and July, reaching $100 \%$ in some municipalities, such as Recife. Kottek et. al (2006) [8] classify the region's climate as humid tropical, with humid fall and winter and a dry summer.

Fig. 3 exhibits the monthly rainfall from 2015 to 2019 for Ville de Paris installed on the studied slope. It also presents the average represented by the trendline. It is observed that the rains concentrate within March and August, with maximum monthly precipitations ranging from $133 \mathrm{~mm}$ to $496 \mathrm{~mm}$, approximately. The maximum rainfall occurred between May and July. September to February can be assumed as a low rainfall period.

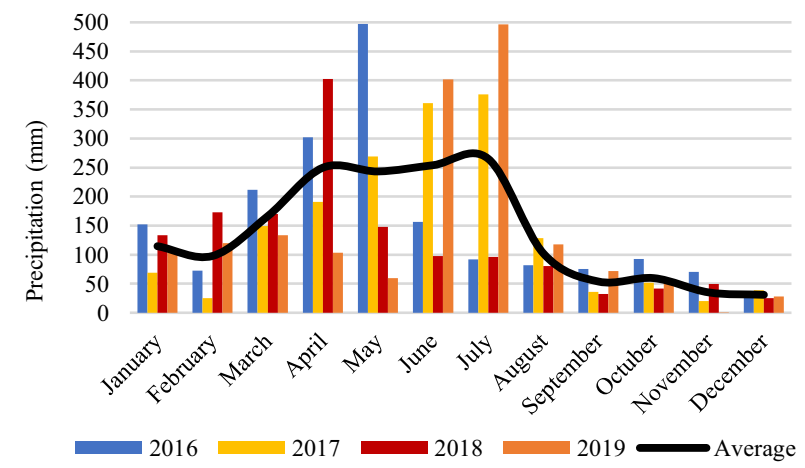

Fig. 3. Accumulated rainfall in study area, Passarinho Recife/PE.
In this period, the higher intensity of the rains leads to a suction reduction in the soil due an increase of the total unit weight and moisture content, that results in a decrease of strength; thus, it alters the soil mechanical properties resulting in possible landslides.

\section{Geotechnical Characterization}

Field and laboratory tests were performed in this study. The field investigation consisted of five Standard Penetration Tests (SPTs) with NSPT obtained in each meter. The SPTs were divided on the slope profile, from the base to the top. Four boreholes points were executed at the heights: SP $04-23 \mathrm{~m}, \mathrm{SP} 03-51 \mathrm{~m}, \mathrm{SP} 02-67 \mathrm{~m}$ and SP $01-78 \mathrm{~m}$. Points 1, 2, 3, and 4 were performed on one side of the slope, forming a section. In this section were collected 4 undisturbed samples for laboratory tests on points 1 and 3 .

The surveys carried out showed that the soil at the top of the slope has low resistance up to about $7 \mathrm{~m}$ in depth with NSPT around 8 . The holes along the slope were slightly more resistant with NSPT between 15 and 20. It was noticed that predominance of sandy soil and the water tabel was found $7.65 \mathrm{~m}$ deep at the toe of slope (SP-04). Fig. 4 shows the NSPT results for each meter for each survey vertical performed.

The laboratory testing campaign performed was: particle size analyses, Atterberg limits, soil-water retention curves, and shear strength determined through direct shear tests in natural and submerged conditions.
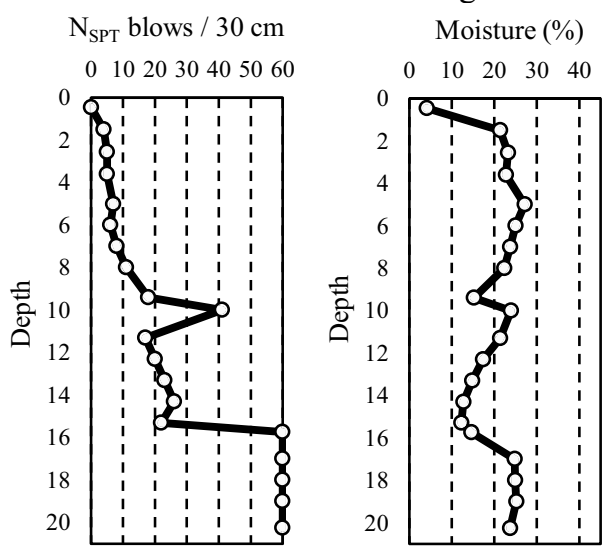

(a)
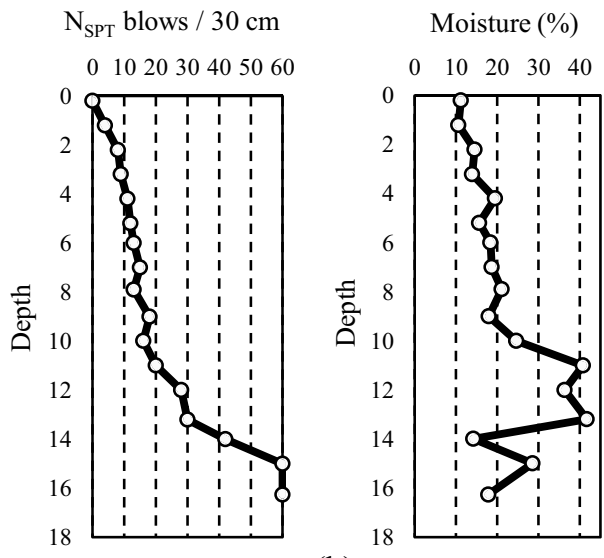

(b)

Fig. 4. (a)Borehole SP-01 e (b)Borehole SP-03, with moisture.

\footnotetext{
* Corresponding author: tahyara.barbalho@ifrn.edu.br
} 
Santana (2006) [9] and Magalhães \& Coutinho (2015) [10] performed field and laboratory tests, on soils characteristics of Barreiras Formation. To define the geotechnical characteristics of the ground, in addition to the tests performed with undisturbed samples collected, the studies mentioned were consulted.

A synthesis of the test results of the particle size analyses and Atterberg limits (physical characterization tests) is illustrated in Table 1. The soil bimodal water retention curves (SWRC, Fig. 5), obtained using the filter-paper method on undisturbed samples and also adapted from Magalhães \& Coutinho (2015) [10] and Santana (2006) [9] shown in Figure 5. The adjustment of the soil retention curves was defined using the methods of Durner (1994) [11] e Seki (2007) [12].

The parameters of effective cohesion (c') and effective internal friction angle $\left(\phi^{\prime}\right)$ were obtained from saturated direct shear tests. The undisturbed samples were in their natural state, being representative of soil layers L1 and L2. All samples were saturated and had normal stress of $25,50,100$ and $200 \mathrm{kPa}$ applied during $24 \mathrm{~h}$. The vertical displacements were recorded during this period and after stabilization. The constant velocity of $0.025 \mathrm{~mm} / \mathrm{min}$ was applied to all samples.

The initial pore water pressure values (suction) used in the flux analyses were obtained from undisturbed samples used in direct shear tests.

\section{Study of stability and flow of the site}

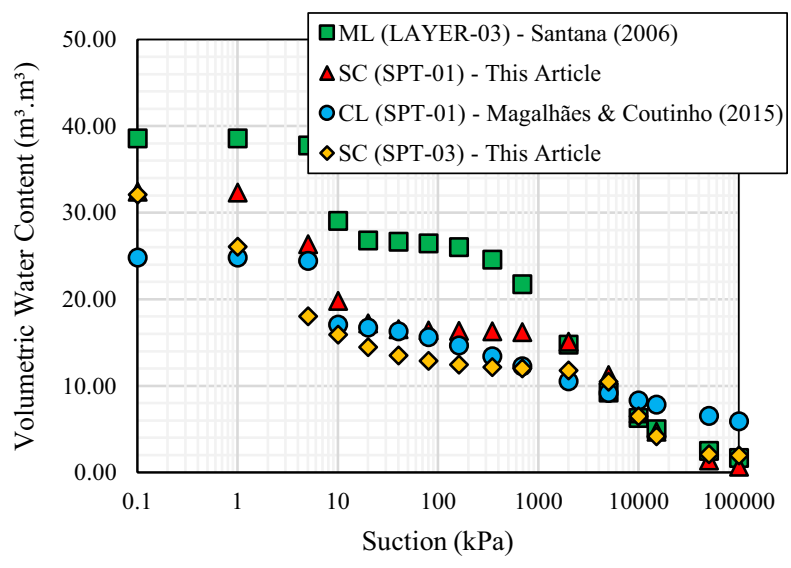

Fig. 5. SWRC for the layers of soils used in analyses.
The occasional landslides events occurred on July 24th 2019 around 5:30 (GMT), according to the local population, on Chagas Ferreira street, Passarinho neighborhood, Recife.

It caused by precipitation around $145 \mathrm{~mm}$ in a few hours. A cut slopes of 2-3 m were made along entire slope to building houses (Fig. 2d). Thus, the terrain had two levels in each cut, one where the house was located and another above the cut with the original slope of the hill.

To determine the slope Safety Factor (SF), 2D stability and flow analyses were performed applying the LEM (limit equibrium methods) and implemented in SLOPE/W and SEEP/W software (2018 version), both developed by GeoStudio.

\subsection{Geometry}

For the creation of the 2D model, data from the Digital Terrain Model (DTM) of RMR, derived from a remotely detected elevation data set collected using LiDAR, were applied with the scale 1: 5000.

Initially, the slope area was cut from the DTM using the ArcMap software, version 10.3. Then, the cut data was exported into a file in ASCII format.

After this step, the geometry as a point cloud was imported to SLOPE/W. In this modality, the software interprets the data and generates a surface; it allows the user to choose a method for interpolating the points. The Linear/Triangulation method was adopted for this analysis.

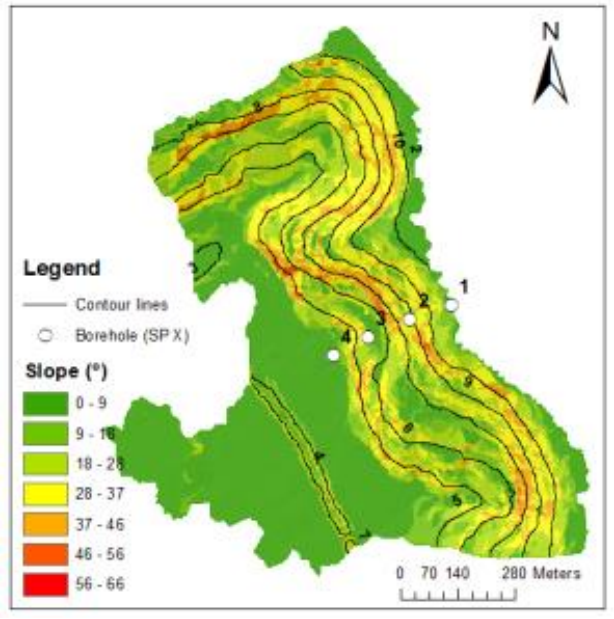

Fig. 6. Contour lines and other slope information.

Table 1. Results of physical characterization tests.

\begin{tabular}{|c|c|c|c|c|c|c|c|c|c|}
\hline \multirow{2}{*}{ References } & \multirow{2}{*}{ Simbol } & \multirow{2}{*}{ Borehole } & \multirow{2}{*}{$\begin{array}{l}\text { Layer } \\
\text { in soil } \\
\text { profile }\end{array}$} & \multirow{2}{*}{$\begin{array}{l}\text { Depth of the } \\
\text { collected } \\
\text { samples (m) }\end{array}$} & \multicolumn{3}{|c|}{ Laboratory Identification Tests } & \multirow{2}{*}{ Description } & \multirow{2}{*}{ SUCS } \\
\hline & & & & & WL(\%) & WP(\%) & $\mathrm{IP}(\%)$ & & \\
\hline This Article & $\Delta$ & SPT 01 & L1 & $0,90-1,20$ & 47 & 29 & 18 & Clayey silty sand & $\mathrm{SC}$ \\
\hline This Article & $\diamond$ & SPT 03 & L2 & $1,25-1,55$ & 34 & 25 & 9 & Clayey silty sand & $\mathrm{SC}$ \\
\hline Santana, 2006 & $\square$ & LAYER 03 & L4 & $3,60-4,00$ & 36 & 24 & 12 & Silty Clayey sand & SM \\
\hline $\begin{array}{c}\text { Magalhães \& } \\
\text { Coutinho, } 2015 \\
\end{array}$ & o & SPT 01 & L3 & $2,00-2,30$ & 38 & 52 & 14 & Silty-sandy clay & CL \\
\hline
\end{tabular}




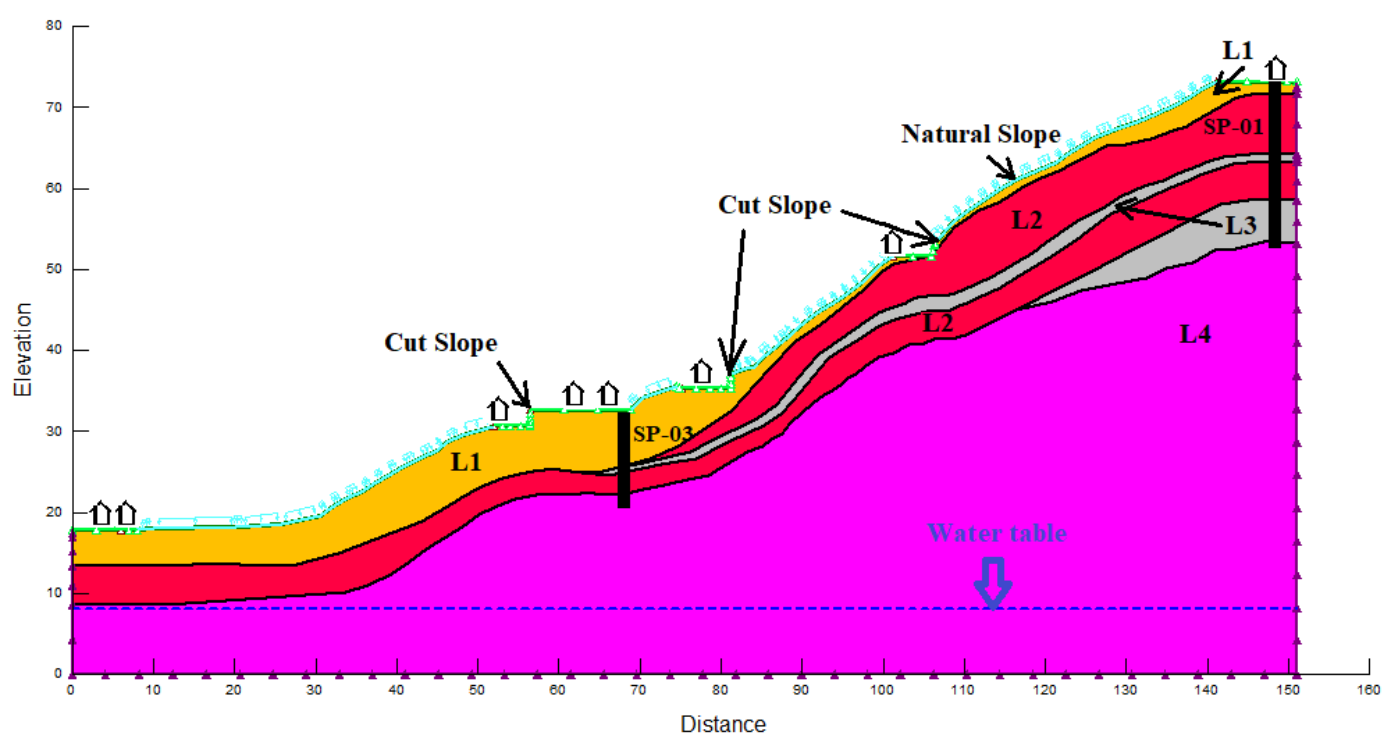

Fig. 7. Slope geometry, geological and geotechnical conditions used on seepage and stability analysis:

Since it is a natural slope, the geometry is complex, with declivities, and alternation between concave and convex sectors, as shown in Fig. 6.

\subsection{Definition of Soil Layers}

After defining the materials, they were arranged in layers according to the geotechnical profiles presented in Figure 7. The method adopted for the interpolation of materials between the boreholes was the Linear/Triangulation.

\subsection{Soil Behavior Model}

The modeling of the stability and seepage consisted of first characterizing the geometry of the slope, the cuts slope and the geological-geotechnical conditions at the site after the field visit. The modeling work was divided in two parts: (1) transient unsaturated seepage analysis; (2) stability analyses coupled with the results from the previous step. For the seepage analysis, accumulated rainfall on 31 days of July was considered (Fig. 8), as well as a leak above the cut slopes. In this case, a pontual leak was considered in the values of of $0.5,1.0$ and $1.5 \mathrm{~m}^{3} /$ day as used Mendes et. al (2018) [13], following SABESP (Basic Sanitation Company of São Paulo State) recommendation (Table 2).

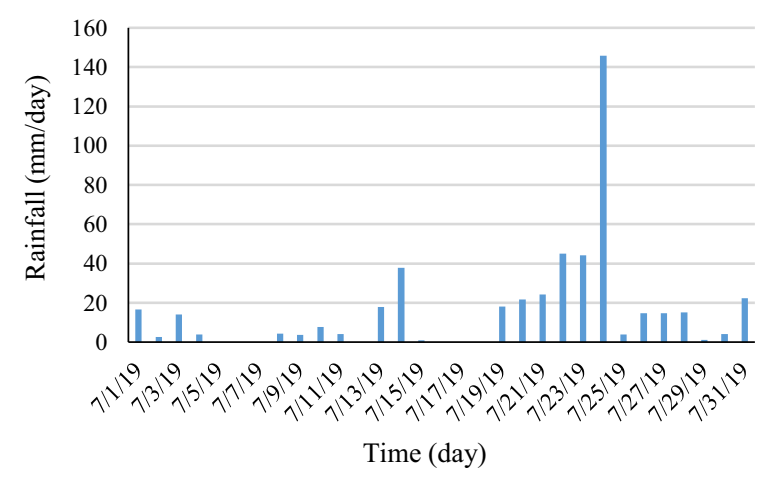

Fig. 8. Daily accumulated rainfall from Jul 1st to 31 th
In the $2 \mathrm{D}$ analysis, the sliding mass is discretized into vertical slices. By the Bishop criterion, the Safety Factor (SF) was used. The material behavior model adopted for stability analysis was the Fredlund et. al (1978) [14] criterion, characterized by being a linear rupture criterion, as presented in Equation 1:

$$
\tau_{f}=c^{\prime}+\left(\sigma_{n}-u_{a}\right) \tan \phi^{\prime}+\left(u_{a}-u_{w}\right) \tan \phi^{b}
$$

Where $\tau_{f}$ is the shear strength of an unsaturated soil; c' is the effective cohesion of saturated soil; $\left(\sigma_{n}-u_{a}\right)$ is the net normal stress on the plane of failure at failure; $\left(u_{a}-u_{w}\right)$ is the matric suction of the soil on the plane of failure; $\phi^{\prime}$ is the effective angle of shearing resistance for a saturated soil and $\phi^{b}$ is the angle of shearing resistance with respect to matric suction.

The parameters shown in Table 3 of soils utilized in layers of soil slope (Fig. 7). The parameters used in the saturated condition. To consider the unsaturated analysis in the software, the unsaturated resistance parameters were estimated according to Vanapalli et. al (1996) [15], as presented in Equation 2:

$$
\tau_{f}=c^{\prime}+\left(\sigma_{n}-u_{a}\right) \tan \phi^{\prime}+\left(u_{a}-u_{w}\right)\left[\tan \phi^{\prime}\left(\frac{s-S_{r}}{100-S_{r}}\right)\right](2)
$$

Where $S_{\mathrm{r}}$ is the residual degree of saturation.

The hydraulic conductivity functions (Fig. 9) were estimated from the SWRC and fitted with the model of Fredlund \& Xing (1994) [16].

Table 2. Seepage for different kinds of leakage (based in Mendes et. al, 2018 [13])

\begin{tabular}{ccc}
\hline Conditions & Kind of Leak & Seepage of leak $\left(\mathrm{m}^{3} /\right.$ day $)$ \\
\hline C1 & Rainfall & 0.0 \\
\hline C2 & Rainfall + Leak 1 & 0.5 \\
\hline C3 & Rainfall + Leak 2 & 1.0 \\
\hline C4 & Rainfall + Leak 3 & 1.5 \\
\hline
\end{tabular}

\footnotetext{
* Corresponding author: tahyara.barbalho@ifrn.edu.br
} 
Table 3. Geotechnical Parameters used in software SLOPE/W.

\begin{tabular}{|c|c|c|c|c|}
\hline Classification & $\begin{array}{c}\text { SC - } \\
\text { Clayey } \\
\text { silty sand }\end{array}$ & $\begin{array}{c}\text { SC - } \\
\text { Clayey } \\
\text { silty sand }\end{array}$ & $\begin{array}{l}\text { CL - Silty- } \\
\text { sandy clay }\end{array}$ & $\begin{array}{c}\text { SM - Silty } \\
\text { Clayey sand }\end{array}$ \\
\hline Layer in soil profile & $\mathrm{L} 1$ & $\mathrm{~L} 2$ & L3 & L4 \\
\hline Simbol & $\diamond$ & $\Delta$ & o & $\square$ \\
\hline Vol. Water Content (\%) & 26.00 & 15.50 & 35.00 & 31.00 \\
\hline Estimated Suction (kPa) & 4.00 & 10.00 & $0-1$ & 10.00 \\
\hline Coesion $(\mathrm{kPa})$ & 10.53 & 2.00 & 8.72 & 8.90 \\
\hline $\operatorname{Phi}\left({ }^{\circ}\right)$ & 34.40 & 40.48 & 34.20 & 29.40 \\
\hline $\begin{array}{l}\text { Unit Weight }\left(\mathrm{kN} / \mathrm{m}^{3}\right) \\
\text { Initial pore water pressure }(\mathrm{kPa})\end{array}$ & $\begin{array}{c}17.62 \\
-10.00\end{array}$ & $\begin{array}{l}21.40 \\
-10.00\end{array}$ & $\begin{array}{c}19.27 \\
-10.00\end{array}$ & $\begin{array}{c}19.43 \\
-10.00\end{array}$ \\
\hline Hydraulic Condutivity $(\mathrm{m} / \mathrm{seg})$ & $3.50 \mathrm{E}-5$ & $1.68 \mathrm{E}-4$ & $5.37 \mathrm{E}-7$ & $1.89 \mathrm{E}-5$ \\
\hline
\end{tabular}
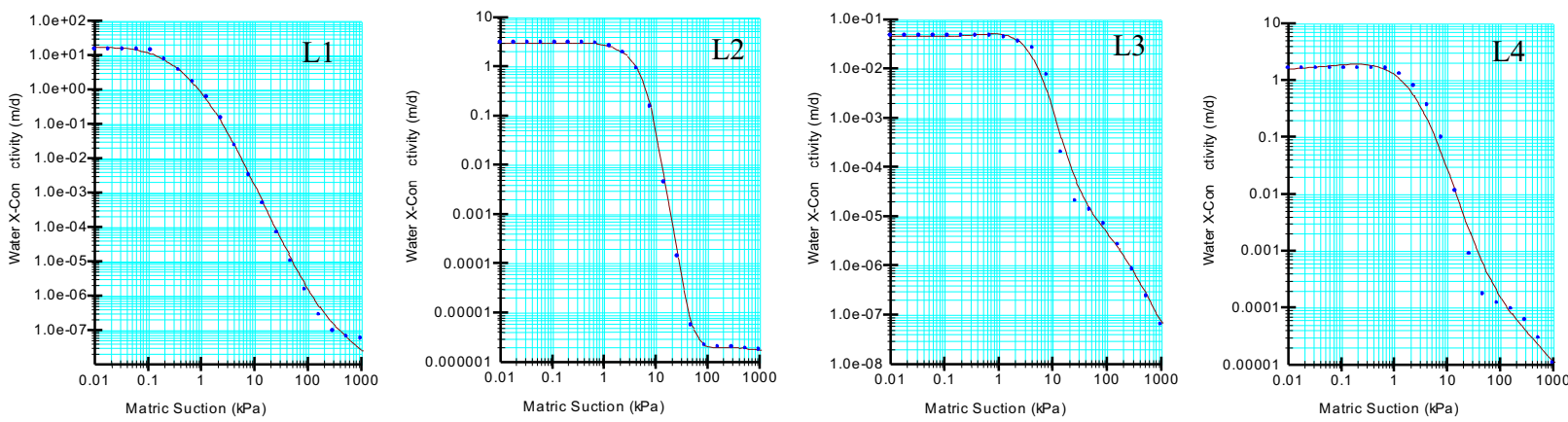

Fig. 9. Hydraulic conductivity functions obtained from the SWRC and fitted with Fredlund, Xing \& Huang's mathematical model.

\subsection{Flow Analyses}

To develop a numerical model by using SEEP / W software, the FEM mesh is generate and the seepage analysis was carried out accordingly. According to the given conditions the up- and down-stream boundary conditions are assigned as Dirichlet and Neumann boundary nodes.

The nodes at the bottom and on the side of the slope are considered with zero-flux (Nuemann) condition. After the development of complete model, it is verified by the
SEEP/W software and computation for different scenarios.

For the condition considering only the rainfall of July, between the 26th and the 29th, perceived that the water table ascend to $4.2 \mathrm{~m}$, continuing below the surface. The pore water pressure, at $13 \mathrm{~m}$ deep, was around $80 \mathrm{kPa}$. A preferential path to the flow of water above the clay layers was created due to its low permeability in relation to the sand layers.

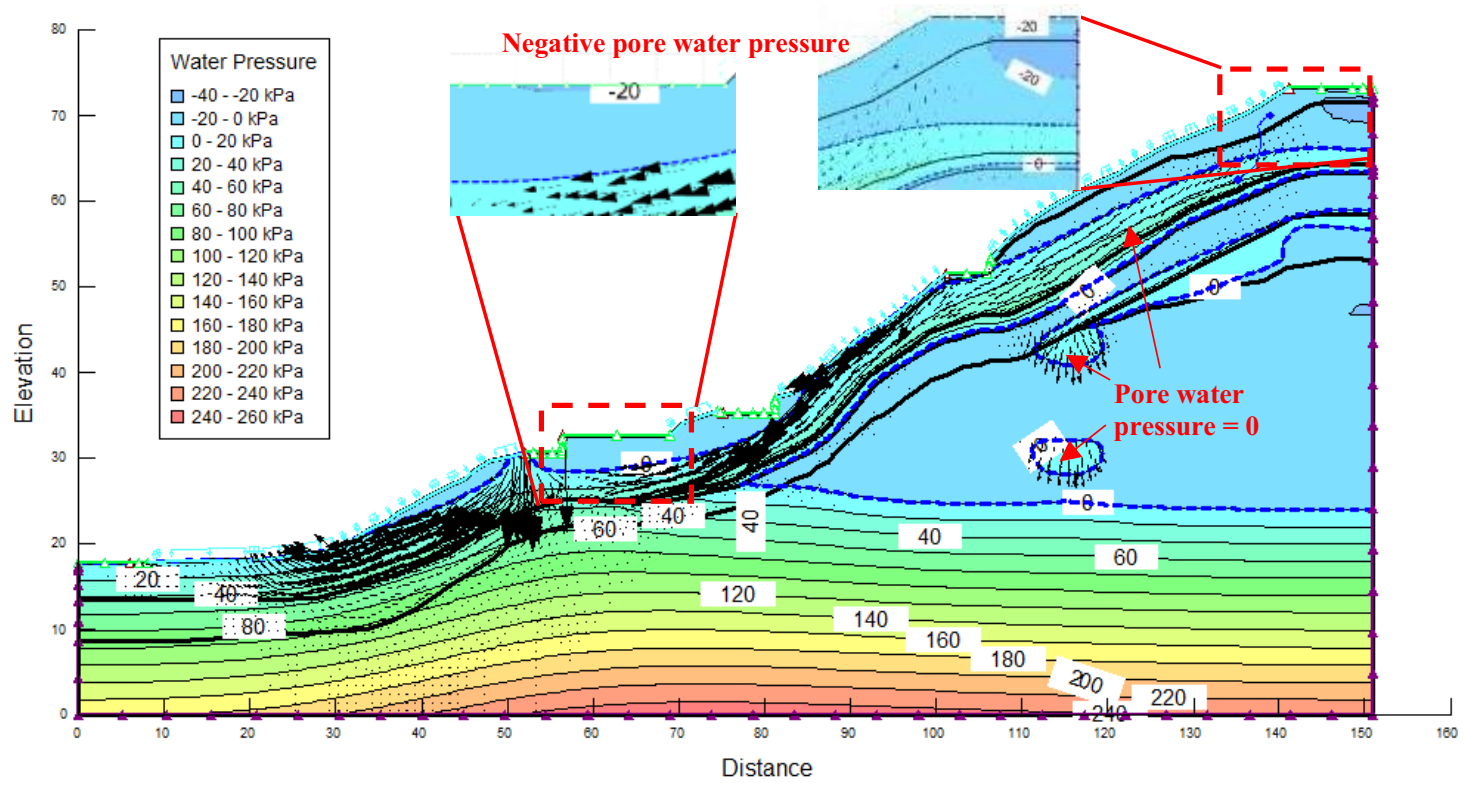

Fig. 10. Water flow and values of pore water pressures on the slope.

\footnotetext{
* Corresponding author: tahyara.barbalho@ifrn.edu.br
} 
When considering the leaks, there is a big change in poro water pressures. For the most unfavorable situation (Rainfall + Leak 3), the water table ascends to the surface creating a considerable area of positive pore water pressure up to around $25 \mathrm{~m}$. At $13 \mathrm{~m}$ in depth, the pore water pressure arrived to $200 \mathrm{kPa}$ and the most superficial layers have a negative pore pressure (suction) of $20 \mathrm{kPa}$ below the cuts where there are built houses. Due to the location of the houses, the water did not seep just below these cuts. Just above the clay layers there was an accumulation of water due to the difficulty of infiltration, and for this reason, the existence of pockets of soil with pore water pressure equal to 0 .

Then, it was possible to observe that, as the intensity of the leaks increased, the pore water pressure values increased considerably at the deepest levels. The water table was also compatible with the increase in the intensity of water infiltration.

\subsection{D Stability analysis results}

The stability analysis was modeling in two conditions, saturated and unsaturated analysis. The porewater pressure used to calculate the FS was estimated from the transient seepage analysis as discussed in 6.3.

All the analyses were conducted considering the method of Bishop using parameters of effective cohesion (c') and effective internal friction angle $(\varphi$ '). Furthermore, the house's weights situated in the toe of cuts along the hillslope were considering like an evenly distributed constant load. The load adopted was of $10 \mathrm{kN} / \mathrm{m}^{3}$.

The results of stability analyzes show failure in the cuts along the hillslope, reached in many cases $\mathrm{SF}<1$ ( $\mathrm{S} 1$, $\mathrm{S} 2$ and $\mathrm{S} 3$ as shown in Figure 11). Thus, the results agree with the rupture process observed in the field inspection after July 24, 2019.

For a deeper critical surface (S4), as shown in Figure 11, the graph of SF over time, Figure 12, demonstrates that the effect of accumulated rainfall, condition $\mathrm{C} 1$, would not lead to the terrain instability, the lowest FS being equaled 1.53. However, hypothetical conditions $(\mathrm{C} 2, \mathrm{C} 3, \mathrm{C} 4)$ considering the effect of rainfall and anthropogenic action, in the form of punctual leaks indicates the potential to occur most critical disaster in the study area. The graph in Figure 12 and Table 4 shows that in unsaturated conditions the SF decreases progressively with the effect of leak infiltration and rainfall until reached the SF around 1.0.

All conditions were also modeled without considering the phi-b, that is, the effect of negative pore pressure. In this case, SF presented convergent and unrealistic values, failing to explain the situations seen in the field.

\section{Conclusions}

The geotechnical investigation effectuated, the parameters adopted from literature, and estimated by the software was adequate for the problem analyzed. It was observed that the increase in moisture content and the decrease in suction during intense precipitation periods combined with leak infiltration reflect the decrease in the safety factor analyses that were conducted.

The results obtained considering the unsaturated condition were more consistent with the reality than saturated analyses that were conducted. Thus, the modelling proved to be representative and can explain the instability phenomena identified in the field, indicating that in the condition with the heavy rains, the slope would fail. .

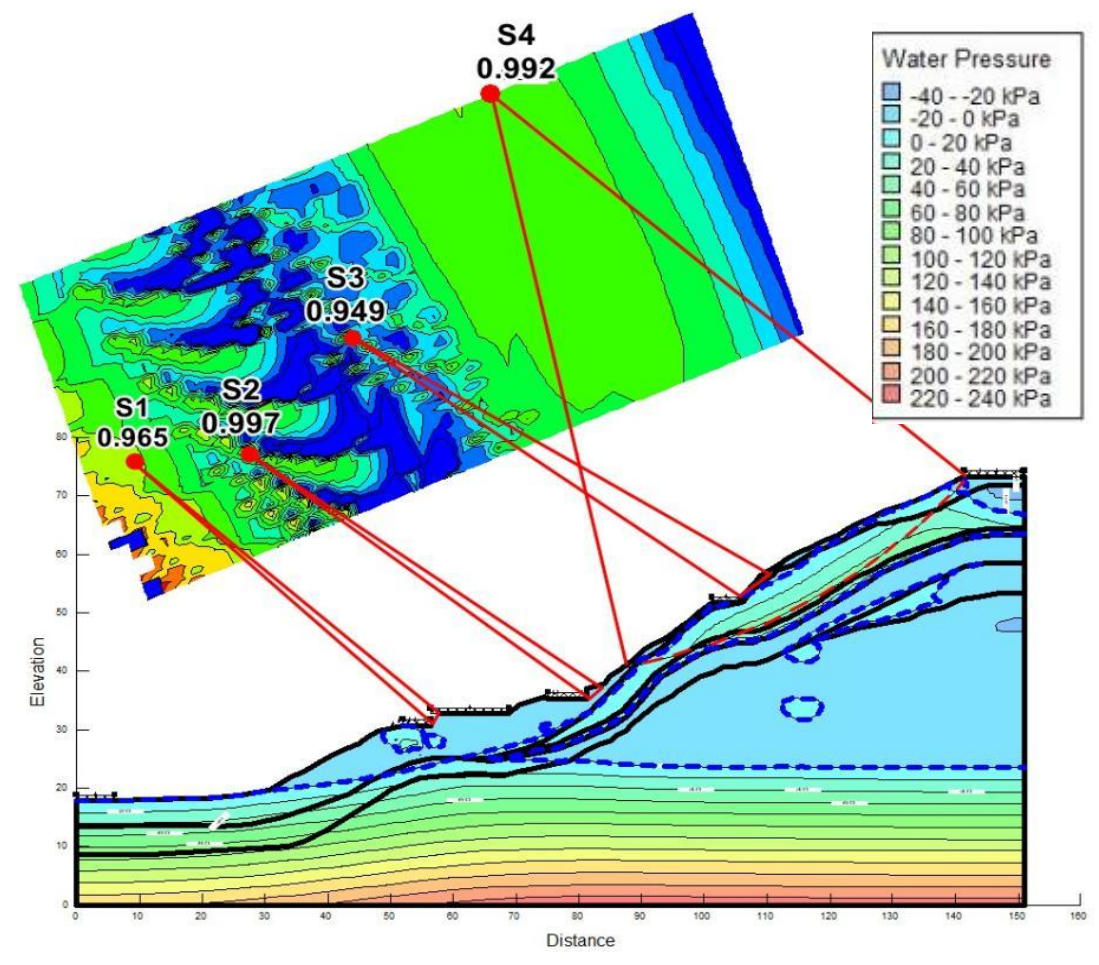

Fig. 11. Results of slope stability analysis in condition C4, after 27 days of rainfall and leak infiltration.

\footnotetext{
* Corresponding author: tahyara.barbalho@ifrn.edu.br
} 


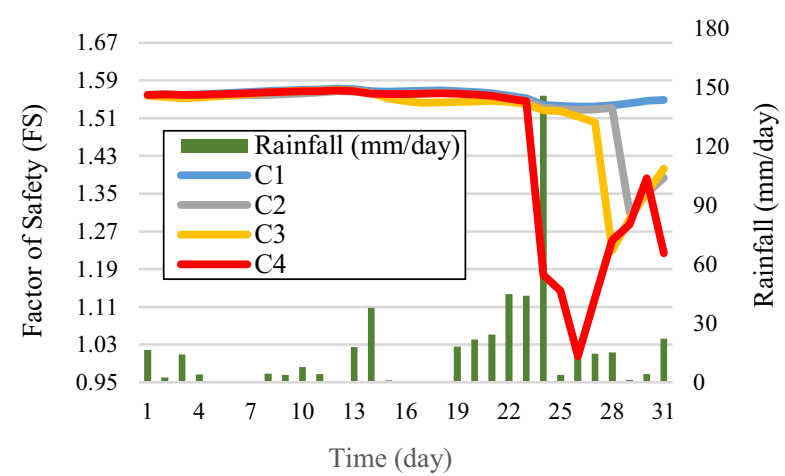

Fig. 12. Results from the factor of safety analysis on a critical surface (S4).

\section{Acknowledgements}

The authors are grateful to National Council for Scientific and Technological Development (CNPq) for the financial support for conducting the research.

\section{References}

1. K. Suguio, A. C. R. Nogueira. (1999) Revisão crítica dos conhecimentos geológicos sobre a Formação (ou Grupo?) Barreiras do Neógeno e o seu possível significado como testemunho de alguns eventos geológicos mundiais. Geociências, 18:2, 439-460.

2. M. M. Alheiros, M. F. A. Lima Filho, F. A. J. Monteiro, J. S. Oliveira Filho. (1998). Sistemas deposicionais na Formação Barreiras do Nordeste Oriental. In: Congresso Brasileiro de Geologia, 35, 1988, Belém (PA). Anais. SBG, v.2: 735-760.

3. M. M. Silva. (2007) Estudo geológico - geotécnico de uma encosta com problemas de instabilidade no municipio de Camaragibe. PhD Thesis, Federal University of Pernambuco.

4. J. Peranić, V. Jagodnik, Ž. Arbanas (2019). Rainfall infiltration and stability analysis of an unsaturated slope in residual soil from flysch rock mass. Geot. Eng. Found. of the future. XVII ECSMGE. doi: https://doi.org/10.32075/17ECSMGE-2019-0906.

5. J. M. Mabesoone. (1991) Revisão geológica da faixa sedimentar costeira de Pernambuco, Paraíba e parte do Rio Grande do Norte. Estudos Geológicos (Série B, Estudos e Pesquisas), v. 10, 252 p.

6. M. M. Alheiros, et al. (1988). Sistemas Deposicionais na Formação Barreiras no Nordeste Oriental. Anais XXXV Congresso Brasileiro de Geologia, Vol. 2, p.753-760.

7. M. M. Alheiros, M. F. Lima Filho. (1991) A Formação Barreiras. Revisão geológica da Faixa Sedimentar Costeira de Pernambuco, Paraíba e Rio Grande do Norte. Estudos Geológicos (Série B Estudos e Pesquisas), v. 10, p. 77-88.

8. M. Kottek, J. Grieser, C. Beck, B. Rudolf, \& F. Rubel. (2006) World map of the Köppen Geiger climate classification updated. Meteorologische Zeitschrift. 15:3, 259-263.
Table 4. Factor of Safety (FS) for different kinds of leakage used in the modelling in critical surface (S4).

\begin{tabular}{cccc}
\hline \multirow{2}{*}{ Conditions } & Kind of Leak & \multicolumn{2}{c}{$\begin{array}{l}\text { Factor of Safety (FS) - } \\
\text { Critical day (29/07/19) }\end{array}$} \\
\cline { 3 - 4 } & & $\begin{array}{c}\text { Considera } \\
\text { ting Phi-b }\end{array}$ & $\begin{array}{c}\text { Without } \\
\text { Phi-b }\end{array}$ \\
\hline C1 & Rainfall & 1.53 & 0.99 \\
\hline C2 & Rainfall + Leak 1 & 1.31 & 0.99 \\
\hline C3 & Rainfall + Leak 2 & 1.23 & 0.99 \\
\hline C4 & Rainfall + Leak 3 & 1.00 & 0.99 \\
\hline
\end{tabular}

9. R. G. Santana. (2006). Análise de soluções de engenharia para estabilização de encostas ocupadas na Região Metropolitana do Recife - PE. Estudo de caso: Ruptura ocorrida em encosta com ocupação desordenada na UR 2, Ibura. PhD Thesis, Federal University of Pernambuco.

10. Magalhães, J. S. L. A. and Coutinho, R. Q (2015). "Slope Stability Study with Sliding Risk in the Municipality Camaragibe / Pernambuco - Brazil". 15th Panamerican. v. 1: 3127-3134.

11. W. Durner. (1994) Hydraulic conductivity estimation for soils with heterogeneous pore structure. Water Resources Research 30:2, 211-223. doi: https://doi.org/10.1029/93WR02676

12. K. Seki. (200). Swrc fit - A nonlinear fitting program with a water retention curve for soils having unimodal and bimodal pore structure. Hydrology and Earth System Sciences, 4, p.407-437. doi: https://doi.org/10.5194/hessd-4-407-2007

13. R. M. Mendes, M. R. M. Andrade, C. A. Graminha, C. C. Prieto, F. F. De Ávila \& P. I. M. Camarinha. Stability Analysis on Urban Slopes: Case Study of an Anthropogenic-Induced Landslide in Sa o Jose' dos Campos, Brazil. Geotech Geol Eng, 36, 599-610. doi: https://doi.org/10.1007/s10706-017-0303-z

14. D. G. Fredlund, N. R. Morgenstern, R. A. Widger. (1978). The shear strength of unsaturated soils. Canadian Geotechnical Journal, 15:3, 313-321. doi: https://doi.org/10.1139/t78-029

15. S. K. Vanapalli, D. G. Fredlund, D. E. Pufahl, A. W. Clifton. (1996). Model for the prediction of shear strength with respect to soil suction. Canadian Geotechnical Journal, 33, 379-392. doi: https://doi.org/10.1139/t96-060

16. D. G. Fredlund, A. Xing. Equations for the soil-water characteristic curve. Canadian Geotechnical Journal, 31:3, 521-532, $1994 . \quad$ doi: https://doi.org/10.1139/t94-061

\footnotetext{
*Corresponding author: tahyara.barbalho@ifrn.edu.br
} 